\title{
Pengaruh Media Powerpoint Berbasis Model Picture and Picture Terhadap Hasil Belajar Materi Virus Kelas X SMA Nurul Iman Tanjung Morawa
}

\author{
Nurhasnah Manurung ${ }^{(1)}$,Dwi Menda Salsalina Sembiring ${ }^{(2)}$ \\ ${ }^{(1)}$ Dosen PNS DPK Kopertis Prodi Pendidikan Biologi FKIP Universitas Islam Sumatera Utara \\ ${ }^{(2)}$ Alumni Program Studi Pendidikan Biologi FKIP-Universitas Islam Sumatera Utara \\ nurhasnahmanurung@ @kip.uisu.ac.id ${ }^{(1)}$, mendasalsa@ gmail.com ${ }^{(2)}$
}

\begin{abstract}
ABSTRAK
Penelitian ini bertujuan untuk mengetahui apakah terdapat pengaruh penggunaan Model Picture and Picture Terhadap Hasil Belajar Materi Virus Kelas X SMA Nurul Iman Tanjung Morawa. Penelitian ini dilaksanakan di SMA Nurul Iman Tanjung Morawa pada bulan Agustus s/d Oktober 2017. Penelitian ini menggunakan metode eksperimen semu (Quasi experiment) dengan populasi penelitian adalah seluruh siswa di kelas X SMA Nurul Iman Tanjung Morawa Tahun Pembelajaran 2017/2018 yang berjumlah 146 orang yang sebanyak 4 kelas, kemudian seluruh populasi dijadikan sampel keseluruhan (total sampling). Instrumen dalam penelitian ini adalah tes hasil belajar berupa pre- test dan post- test. Hasil belajar siswa yang menggunakan model Cooperative Integrated Reading and Composition diperoleh nilai siswa yang tuntas sesuai Kriteria Ketuntasan Minimal (KKM) 70 adalah sebanyak 32 orang (80\%) dan yang tidak tuntas sebanyak 8 orang $(20 \%)$ dengan nilai rata- rata 77,95 dan standart deviasi 9,55 . Hasil uji normalitas diperoleh Lo $<\mathrm{L}_{\text {tabel }}$ yaitu $0,1131<0,1401$ dinyatakan bahwa data berdistribusi normal sedangkan hasil uji homogenitas diperoleh $\mathrm{F}_{\text {hitung }}<\mathrm{F}_{\text {tabel }}=1,1<1,71$ dinyatakan data mempunyai varians yang sama atau homogen. Hasil uji hipotesis menggunakan uji t diketahui rata- rata dari perbedaan pre test dengan post test adalah sebesar 15,45 dan jumlah kuadrat deviasi sebesar 2127,9 dengan nilai ini maka diperoleh $t_{\text {hitung }}>t_{\text {tabel }}$ atau 13,21 > 1,68 maka Ha diterima dan Ho ditolak, sehingga dinyatakan bahwa ada pengaruh yang signifikan penggunaan model Cooperative Integrated Reading and Composition terhadap hasil belajar siswa pada materi ekosistem
\end{abstract}

Kata kunci : Cooperative Intgrated Reading Composition, Hasil Belajar Siswa

\section{PENDAHULUAN}

Pada proses belajar mengajar ada interaksi atau hubungan timbal balik antara siswa dengan guru dimana siswa menerima bahan pelajaran yang diajarkan oleh guru. Guru mengajar dengan membimbing siswa, mengarahkan siswa, memahami bahan pelajaran sesuai dengan tujuan sehingga siswa tersebut dapat mengembangkan minat, kreatifitas, dan kemampuan yang ada pada dirinya. Menurut Syah (2010:87) belajar adalah kegiatan yang berproses dan merupakan unsur yang sangat fundamental dalam penyelenggaraan setiap jenis dan jenjang pendidikan. Ini berarti bahwa hasil belajar atau gagalnya pencapaian tujuan pendidikan itu amat bergantung pada proses belajar yang dialami siswa, baik ketika ia berada disekolah maupun dilingkungan rumah atau keluarganya sendiri. Oleh karena itu, pemahaman yang bena rmengenai arti belajar dengan segala aspek, bentuk, dan manifestasinya mutlak diperlukan oleh parapendidik khususnya guru. Kekeliruan atau ketidak lengkapan persepsi mereka terhadap proses belajar dan hal-hal yang berkaitan dengannya mungkinakan dan mengakibatkan kurang bermutunya hasil pembelajaran yang dicapai peserta didik. Menurut Susilana dan Riyana (2009:01) pembelajaran merupakan suatu kegiatan yang melibatkan seseorang dalam upaya memperoleh pengetahuan, keterampilan dan nilai-nilai positif dengan memanfaatkan sumber untuk belajar. Pembelajaran dapat melibatkan dua pihak yaitu siswa sebagai pembelajaran dan guru sebagai fasilitator, yang terpenting dalam kegiatan pembelajaran adalah terjadinya proses belajar (learn-ing process).Proses perancangan pembelajaran selalu diawali dengan 
perumusan tujuan instruksional khusus sebagai pengembangan dari tujuan instruksional umum. Berdasarkan hasil wawancara peneliti dengan guru Mata Pelajaran Biologi pada tanggal 20 juli 2017 jam 16:00 WIB di SMA Nurul Iman Tanjung Morawa diperoleh infomasi bahwa nilai Kriteria Ketuntasan Minimal (KKM) yang ditetapkan oleh pihak sekolah tersebut adalah 65,00, dan diketahui bahwa pada saat Ujian Akhir Semester Genap siswa kelas X Tahun Pembelajaran 2016/2017.Terdapat sekitar 50\% dari jumlah keseluruhan siswa kelas $\mathrm{X}$ yaitu 72 orang yang mampu mencapai KKM, sedangkan 72 orang lainnya belum mencapai KKM. Upaya dalam mengatasi masalah tersebut, guru harus memiliki perencanaan sebelum melakukan proses belajar mengajar sehingga siswa mampu terpacu dan termotivasi dalam keaktifan siswa menyampaikan pendapatnya mengenai materi yang telah disampaikan. Salah satunya yang dapat meningkatkan keberhasilan belajar siswa adalah penggunaan media pembelajaran berbasis model pembelajaran yang tepat. Penentuan dalam memilih media pembelajaran berbasis model pembelajaran harus sesuai karakteristik komponen penggunaannya. Setelah itu guru mementukan alat dan melaksanakan proses belajar. Penggunaan media pembelajaran berbasis model pembelajaran merupakan sebagai salah satu komponen yang tidak berdiri sendiri tetapi saling berhubungan dengan komponen lainnya dalam rangka menciptakan situasi belajar yang diharapkan. Seorang guru dituntut menggunakan media pembelajaran pada materi pelajaran yang diajarkan sebagai suatu pelajaran yang dapat mengembangkan kemampuan berpikir kritis siswa dan memahami berbagai media pembelajaran yang dapat merangsang kemampuan siswa untuk belajar serta juga memiliki keterampilan dalam memahami suatu materi pembelajaran. Apabila guru berhasil menciptakan suasana yang membuat siswa termotivasi dan aktif dalam belajar, maka kemungkinan hasil belajar dapat meningkat. Media Powerpoint adalah media visual yang di proyeksikan melalui alat yang disebut dengan proyektor slide (Sisilana dan Riyana 2009:18). Media pembelajaran ini salah satu aplikasi yang paling banyak digunakan oleh orang-orang dalam mempersentasekan baha najar. Powerpoint digunakan dalam contoh dan sub bab. Dalam pembuatannya sebuah presentase sesuaikanlah judul presentase dengan tema yang akan kita gunakan, karena kedua hal ini akan mempengaruhi suasana atau susunan slide. Menurut Kurniasih dan Sani (2016 : 44) menyatakan bahwa model pembelajaran picture and picture merupakan model pembelajaran yang kooperatif atau mengutamakana danya kelompok-kelompok dengan menggunakan media gambar yang dipasangkan atau diurutkan menjadi urutan logis

\section{METODE PENELITIAN}

\section{A. Prosedur Penelitian}

\section{Tahap Persiapan}

Adapun kegiatan yang dilakukan pada tahap persiapan ini antara lain :

a. Mengajukan surat permohonan observasi kepada FKIP UISU

b. Observasi ke SMA Nurul Iman Tanjung Morawa dan meminta izin mengadakan penelitian dengan pihak sekolah.

c. Mengadakan wawancara serta konsultasi dengan guru Biologi yang mengajar di kelas $\mathrm{X}$ untuk menentukan materi pelajaran yang akan diajarkan.

d. Mempersiapkan perangkat pembelajaran sesuai dengan media powerpoint Berbasis Model Pictuten And Picture.

e. Membuat powerpoint tentang Virus beserta gambarnya.

f. Menyusun proposal penelitian dengan arahan dosen pembimbing.

g. Menyusun rencana pelaksanaan pembelajaran.

h. Menyusun instrumen penelitian yakni soal pilihan ganda 
i. Melakukan uji coba instrumen, yakni di SMA Nurul Iman Tanjung Morawa yang telah disusun untuk digunakan dalam penelitian yang meliputi uji indeks kesukaran, uji daya beda, uji validitas dan reliabilitas test.

j. Mengurus surat izin penelitian dari fakultas untuk ditembuskan ke sekolah SMA Nurul ImanTanjung Morawa.

\section{Tahap Pelaksanaan}

Adapun kegiatan yang dilakukan pada tahap pelaksanaan ini antara lain :

Pertemuan I :

a. Melakukan Pre-test sebelum materi diajarkan

b. Menyajikan materi beserta bahan ajar yang diperlukan

c. Melakukan pembelajaran dengan Media Powerpoint Berbasis Model Picture And Picture

Pertemuan II :

a. Melanjutkan pembelajaran pada indikator selanjutnya

b. Menampilkan powerpoint beserta gambar pada materi Virus

c. Meminta siswa untuk menganalisis powerpoint beserta gambar pada materi Virus.

d. Membimbing dan mengarahkan siswa tentang powerpoint Berbasis Model Picture And Picture yang ditampilkan. Model pembelajaran picture and picture adalah model pembelajaran yang memnanfaatkan gambar yang didalamnya terdapat aktivitas untuk memasang atau mengurutkan gambar menjadi urutan yang logis.

e. Melakukan Tanya jawab dengan siswa

f. Melakukan post-test kepada siswa

\section{Tahap Penyelesaian}

Adapun kegiatan yang dilakukan pada tahap penyelesaian ini antara lain :

a. Melakukan pengolahan data

b. Proses analisis data

c. Menarik kesimpulan

d. Menyusun laporan dan melengkapi lampiran-lampiran yang berhubungan dengan penelitian.

\section{Teknik Analisis Data}

Menurut Sudjana (2005:67), Data yang diperoleh dari hasil penelitian dianalisis dengan langkah-langkah sebagai berikut :

1. Menentukan daftar distribusi frekuensi dengan rumus sudjana (2005:47)
a. Menentukan data tertinggi dan data terendah
b. Menentukan range $(\mathrm{R})$ dari setiap kelas
c. Menentukan jumlah atau banyak kelas $B K=1+(3,3) \log n$
d. Menentukan panjang kelas interval : $\mathrm{P}=\mathrm{R} / \mathrm{BK}$

2. Menentukan nilai rata-rata (mean) dan standar deviasi dari setiap kelas.

a. Nilai rata-rata (Mean)

$$
\bar{X}=\frac{\sum f i . x i}{\sum f i} \text { Sudjana (2006:67) }
$$

Keterangan :

$\bar{X}=$ Nilai rata-rata

$\mathrm{Fi}=$ Frekuensi nilai

$\mathrm{Xi}=$ Jumlah nilai siswa

b. Standar Deviasi atau disebut simpangan baku dapat dihitung dengan menggunakan rumus sebagai berikut: 


$$
S^{2}=\frac{n \sum f i \cdot x i^{2}-\left(\sum f i \cdot x i\right)^{2}}{n(n-1)}
$$

Sudjana (2005:95)

Keterangan :

$S^{2}=$ Varians

$\mathrm{S}=$ Simpangan Baku

$\mathrm{n}=$ Jumlah Seluruf Siswa

fi $=$ Jumlah Frekuensi Siswa

$\mathrm{Xi}=$ Nilai Ke1 Yang Diperoleh

Nilai kuadrat dari standart dari Standart (S) atau simpangan baku dinamakan varians

\section{HASIL PENELITIAN}

Dari hasil distribusi untuk $\alpha=0,05$ dan $\mathrm{dk}=(\mathrm{n}-1)=(32-1)=31$ diperoleh $\mathrm{t}_{\text {tabel }}=1,698$ dan $t_{\text {hitung }}=2,326$. Jika nilai $t_{\text {hitung }}$ dibandingkan dengan $t_{\text {tabel }}$ maka $t_{\text {hitung }}>t_{\text {tabel }}=2,326>$ 1,698.sehingga $\mathrm{H}_{\mathrm{a}}$ diterima dan $\mathrm{H}_{\mathrm{o}}$ ditolak. Dengan demikian disimpulkan ada pengaruh yang signifikan penggunaan MediaPowerpoint berbasis Model Pembelajaran Picture And Picture terhadap hasil belajar siswa pada materi Virus dikelas X-2 SMA Nurul Iman Tanjung Morawa Tahun Pembelajaran 2017/2018. (Perhitungan terdapat pada lampiran 24 halaman 167).

Penerimaan Ha dapat digambarkan melalui kurva dibawah ini:

Daerah

Daerah

Penerimaan Ha

Penerimaan $\mathrm{Ha}$

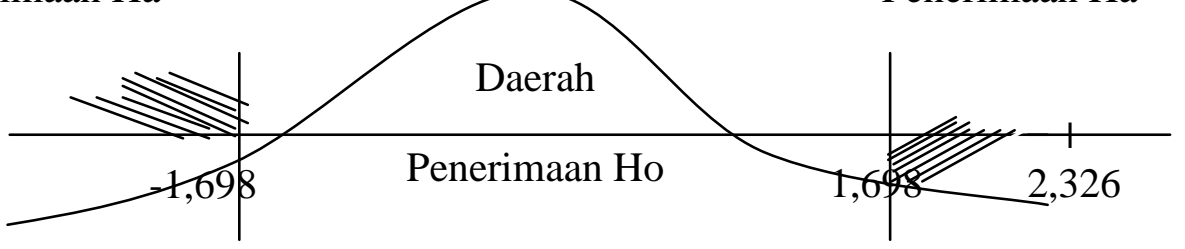

\section{Gambar Kurva Pengujian Hipotesis Penelitian}

Setelah dilakukan perhitungan pada data hasil penelitian diperoleh hasil belajarsiswa pada materi Virusmengalamipeningkatan. Pada saat dilakukan pre test terdapat 2 orang siswa dinyatakantuntas (6\%), sedangkan 30 siswa lainnya dinyatakan tidak tuntas (94\%) dengan nilai rata-rata 52,88 dan standart deviasi 8,33 . Setelah diberi pengajaran menggunakan media powerpoint berbasis model pembelajaran Picture And Picture pada saat post test siswayang mendapat nilai tertinggi yaitu 80,00 sebanyak 5 orang dan nilai terendah 40,00 sebanyak 1 orang. Maka siswa yang tuntas sebanyak 25 siswa (78\%) dan 7 siswa (22\%) tidak tuntas dengan nilai rata-rata 67,93 dan standart deviasi 9,88. Nilai diatas menunjukkan adanya pengaruh yang positif terhadap hasil belajar siswayang diajarkan menggunakan media powerpointberbasis model pembelajaran Picture And Picture.Peningkatan hasil belajar dengan menggunakan media powerpoint berbasis model pembelajaran Picture And Picture. Pada perhitungan uji normalitas dan uji homogenitas diperoleh data berdistribusi normal dan homogen. Setelah dilakukan pengujian hipotesis

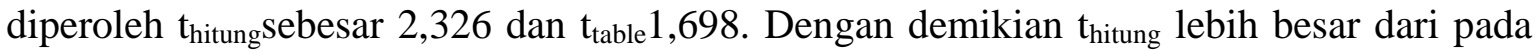
$t_{\text {tabel }}$ atau 2,326> 1,698.Berdasarkan data ini maka hipotesis alternatif (Ha) diterima dan hipotesis nol (Ho) ditolak. Dengan demikian dapat disimpulkan ada pengaruh yang signifikan penggunaan MediaPowerpoint berbasis Model Pembelajaran Picture And 
Picture terhadap hasil belajar siswa pada materi pokok Virus di kelas X-2 SMA Nurul Iman Tanjung Morawa Tahun Pembelajaran 2017/2018. Dari hasil Penelitian ini menunjukan bahwa dengan pembelajaran menggunakan media powerpoint berbasis model pembelajaran Picture And Picture dapat meningkatkan hasil belajar siswa dan dapat meningkatkan aktivitas siswa dalam kegiatan pembelajaran, serta menambah ingatan siswa dalam kegiatan belajar mengajar di kelas. Kurniasih dan Sani dalam Ragam pengembangan model pembelajaran (2016:44) menyatakan bahwa model pembelajaran picture and picture merupakan model pembelajaran yang kooperatif atau mengutamakan adanya kelompokkelompok dengan menggunakan media gambar yang dipasangkan atau diurutkan menjadi urutan logis. Dengan model ini siswadiajak sadar dan terencana untuk mengembangkan interaksi diantara mereka agar bisa saling asah, saling asih dan saling asuh. Model pembelajaran ini mengandalkan gambar sebagai media dalam proses pembelajaran. Dalam pelaksanaan model pembelajaran picture and picture ini siswa dituntut harus bertanggung jawab atas segala sesuatu yang dikerjakan dalam kelompoknya. Istarani (2011:2017) menyatakan bahwa suatu rangkaian penyampaian materi ajar dengan menunjukan gambargambar kepada siswa sehingga siswa dapat memahami secara jelas tentang makna hakiki dan materi ajar menunjukkan gambar-gambar kepada siswa sehingga siswa dapat memahami secara jelas tentang makna hakiki dari materi ajar yang disampaikan kepadanya. Jadi bahan utama dari penggunaan model picture and picture adalah gambargambar yang menyangkut materi pembelajaran tanpa ada gambar, tidak mungkin bisa dilakukan proses belajar mengajar dengan menggunakan model picture and picture.

\section{KESIMPULAN}

Berdasarkan uraian penelitian diatas maka dapat diambil beberapa kesimpulan, yaitu:

1. Nilai rata-rata pre test sebelum menggunakan media powerpoint berbasis model pembelajaran Picture and Picture adalah 52,88 dan standart deviasi 8,83. Maka dapat dinyatakan bahwa terdapat 2 orang siswa yang tuntas (6\%) sedangkan 30 siswa lainnya dinyatakan tidak tuntas (94\%). Pada materi Virus dikelas X-2 SMA Nurul Iman Tanjung Morawa Tahun Pembelajaran 2017/2018

2. Nilai rata-rata post test hasil belajar siswa yang diajarkan menggunakan media powerpoint berbasis model pembelajaran Picture and Picture adalah 67,93 dan standart deviasi 9,88. Terdapat 25 orang siswa (78\%) yang tuntas dan 7 orang (22\%) tidak tuntas. Pada materi Virus di Kelas X-2 SMA Nurul Iman Tanjung Morawa Tahun Pembelajaran 2017/2018. Bila dilihat dari nilai pre test dan post test nilai ratarata dan standart deviasi maupun ketuntasan hasil belajar Biologi siswa kelas X-2 mengalami peningkatan hasil belajar setelah menggunakan media powerpoint berbasis model pembelajaran Picture and Picture.

3. Hasil Hipotesis dalam penelitian ini yaitu Ha diterima dan Ho ditolak dengan nilai diperoleh $t_{\text {hitung }}>t_{\text {tabel }}$ atau2,326 $>1$,698. Maka dari hasil analisa terhadap rumusan hipotesis menunjukkan bahwa ada pengaruh yang signifikan penggunaan Media Powerpoint berbasis Model Pembelajaran Picture And Picture terhadap hasil belajar siswa pada materi Virus dikelas X-2 SMA Nurul Iman Tanjung Morawa Tahun Pembelajaran 2017/2018 
Dwi Menda SS, Nurhasnah Manurung : Pengaruh Media Powerpoint Berbasis Model Picture and Picture Terhadap Hasil Belajar Materi Virus Kelas X SMA Nurul Iman Tanjung Morawa

\section{SARAN}

Beberapa saran yang diusulkan berdasarkan penelitian, maka peneliti memberikan beberapa saran yaitu :

1. Penggunaan media powerpoint berbasis model pembelajaran Picture and Picture sebagai salah satu solusi untuk meningkatkan hasil belajar siswa.

2. Diharapkan bagi siswa dapat mempermudah untuk memahami dan menerima materi pembelajaran Biologi khususnya pada materiVirus.

3. Bagi peneliti (calon guru) sebagai bahan persiapan diri menjadi guru dan menambah wawasan peneliti tentang proses belajar mengajar dengan menggunakan media powerpoint berbasis model pembela jaran Picture and Picture.

\section{DAFTAR PUSTAKA}

Arikunto, Suharsimi. (2016). Dasar-dasar Evaluasi Pendidikan. Jakarta: Bumi Aksara.

Arsyad. (2015). Media Pembelajaran. Jakarta: PT Raja Grafindo Persada.

Daryanto. (2010). Belajar dan Mengajar. Bandung: YramaWidya.

Dimyanti dan Mudjiono. (2013). Belajar dan Pembelajaran. Jakarta: Rineka Cipta.

Djamarah dan Zain. (2013). Strategi Belajar Mengajar. Jakarta: Rineka Cipta.

Handayani,Husna F.(2013). Pembelajaran Berbasis Virtual Meningkatkan Berfikir Kritis dan Sikap Siswa kelas X Pada Materi Invertebrata Bandung:.Bandung: UPI Press.

Irnaningtyas. (2013). Biologi untuk SMA/MA :Jakarta : Erlangga

Purwanto.( 2009). EvaluasiHasilBelajar.Yogyakarta.PustakaPelajar.

Ngalimun.(2015). Staretegidan Model Pembelajaran. Yogyakarta: Aswaja Pressindo.

Nurhayati, Nunung (2012).Biologi Bilingual untuk SMA/MA Kelas X Jakarta.

Slameto.( 2013).BelajardanFaktor-Faktor yang Mempengaruhi.Jakart: Rineka Cipta.

Sudjana. (2009).Metode Statistika. Bandung: Tarsito.

Suprijono, Agus.(2012).Cooperative Learning.Yogyakarta :Pustaka Pelajar.

Surya, Mohamad. (2015). Strategi Kognitif dalam Proses Pembelajaran. Bandung: Alfabeta.

Susilana dan Riyana. (2009). Media Pembelajaran. Bandung: Cv.Wacana prima.

Syah, Muhibbin. (2010). Pisikologi Pendidikan. Bandung: Remaja Rosdakarya.

Trianto. (2009). Mendesain Model Pembelajaran Inovatif-Progresif. Jakarta: Putra Grafika. 